\title{
DAMPAK PROGRAM BANTUAN SOSIAL TERHADAP PERTUMBUHAN EKONOMI DAN KEMISKINAN KABUPATEN TERTINGGAL DI INDONESIA
}

\author{
The effect Of Social Aid To Economic Growth And Poverty \\ On Underdeveloped Areas in Indonesia
}

Edo Pramana Putra ${ }^{1}$, Yeti Lis Purnamadewi ${ }^{2}$, Sahara ${ }^{2}$

Diterima: 7 Juli 2015

Disetujui: 24 Agustus 2015

\begin{abstract}
Abstrak: Persoalan daerah tertinggal dan masalah ketimpangan pembangunan merupakan permasalahan disparitas wilayah yang membahayakan kesatuan nasional. Tujuan penelitian ini adalah mengkaji dinamika kemiskinan dan dinamika bantuan sosial di daerah tertinggal, menganalisis pengaruh bantuan sosial Kementerian daerah tertinggal terhadap pertumbuhan ekonomi di daerah tertinggal, dan menganalisis hubungan antara pertumbuhan ekonomi dengan penurunan kemiskinan di kabupaten tertinggal di Indonesia. Hasil penelitian menunjukkan terjadi dinamika kenaikan dan penurunan penduduk miskin di daerah tertinggal di Indonesia dalam kurun waktu tahun 2010-2013. Dari hasil analisis regresi model data panel pertumbuhan ekonomi diketahui bahwa variabel bantuan kelembagaan sosial dan budaya, bantuan infrastruktur, dan bantuan ekonomi dan dunia usaha signifikan meningkatkan pertumbuhan ekonomi di daerah tertinggal, sedangkan bantuan sumberdaya manusia dan bantuan daerah khusus tidak signifikan didalam meningkatkan pertumbuhan ekonomi di daerah tertinggal. Dari hasil analisis regresi model data panel kemiskinan diketahui bahwa variable PDRB tidak signifikan mempengaruhi tingkat kemiskinan, yang signifikan mempengaruhi tingkat kemiskinan di daerah tertinggal adalah variabel jumlah pengangguran, IPM, dan share sektor jasa
\end{abstract}

Kata Kunci: Daerah tertinggal, bantuan sosial, kemiskinan, pertumbuhan ekonomi, data panel

Abstract: The issue of underdeveloped areas and the problems of inequality of development is the disparity problem areas that endanger national unity. The purpose of this study is to examine the dynamics of poverty and the dynamics of social aid in underdeveloped areas, to analyze the effect of social aid Ministry of underdeveloped areas to economic growth in underdeveloped areas, and to analyze the relationship between economic growth and poverty reduction in underdeveloped area in Indonesia. The results

\footnotetext{
${ }^{1}$ Program Studi Ilmu Perencanaan Pembangunan Wilayah dan Perdesaan, Institut Pertanian Bogor

${ }^{2}$ Program Studi Ilmu Ekonomi Institut Pertanian Bogor
} 
showed the increase dynamics and decline of poor people in underdeveloped areas in Indonesia within the period 2010-2013. From the results of regression analysis of panel data model of economic growth known that variable social and cultural institutional support, infrastructure support, and help the world economy and a significant effort to increase economic growth in underdev eloped areas, while the human resources aid and specific support area is not significant in improving economic growth in underdeveloped regions. The results of the regression analysis poverty panel data model known that the variable number of unemployed, IPM, and the share of the services sector significantly affect to the level of poverty in underdeveloped areas, while the variable PDRB, the share of agriculture and industry sector share is not significant in influencing to the poverty level in underdeveloped area.

Keywords:Underdeveloped Areas, Social Aid, Poverty, Economic Growth, Panel Data

\section{Pendahuluan}

Persoalan daerah tertinggal adalah salah satu dampak dari masalah ketimpangan pembangunan yang dapat membahayakan kesatuan nasional. Menurut Bappenas, daerah tertinggal ditandai dengan rendahnya aksesibilitas pelayanan sarana dan prasarana ekonomi dan sosial serta letak geografis yang relatif terpencil atau wilayah yang miskin sumberdaya alam atau rawan bencana (Bappenas, 2013). Secara makro ketimpangan pembangunan yang signifikan terjadi antara desa-kota, antara Kawasan Timur Indonesia (KTI) dan Kawasan Barat Indonesia (KBI), antara wilayah Jawa dan luar Jawa, dan sebagainya (Bappenas, 2013).

Sejak tahun 2009 diberikan dana bantuan sosial kepada daerah tertinggal dengan total Rp 1,41 triliun sampai tahun 2013(Kementerian PDT, 2013). Dana bantuan sosial diberikan untuk mempercepat pembangunan daerah tertinggal, kegiatan yang dilakukan diarahkan pada sektor produktif atau investasi pada bidang social overhead, seperti pembangunan jalan, fasilitas kesehatan, pendidikan dan prasarana infrastruktur lainnya (Aziz, 1994).

Rata-rata pertumbuhan ekonomi daerah tertinggal berfluktuatif dengan ratarata 5 persen pertahun, dengan tingkat kemiskinan yang masih tinggi dari rata-rata kemiskinan nasional yaitu 16,13 persen. Kebijakan percepatan pembangunan daerah tertinggal sangat diperlukan mengingat masih banyaknya kabupaten yang masuk kategori sebagai daerah tertinggal, yakni 133 kabupaten atau 32,2 persen dari jumlah kabupaten di Indonesia.

Studi mengenai dampak pemberian bantuan sosial perlu dilakukan untuk mengetahui sejauh mana efektifitas dari pemberian bantuan sosial tersebut dalam mengatasi permasalahan daerah tertinggal. Berdasarkan kondisi tersebut, tujuan penelitian ini adalah : (1) Mengkaji dinamika kemiskinan, perekonomian, dan bantuan sosial di kabupaten tertinggal di Indonesia (2) Menganalisis pengaruh program bantuan sosial Kementerian PDT terhadap pertumbuhan ekonomi kabupaten tertinggal di Indonesia, (3) Menganalisis hubungan antara pertumbuhan ekonomi dengan penurunan kemiskinan di kabupaten tertinggal di Indonesia.

\section{Metode Penelitian}

\section{Jenis dan Sumber Data}

Data yang digunakan dalam penelitian ini adalah data sekunder dari berbagai publikasi Badan Pusat Statistik (BPS), diantaranya publikasi PDRB, angka IPM, jumlah penduduk miskin, jumlah penduduk, tingkat pengangguran, share sektor 
pertanian, industri dan jasa. Data mengenai bantuan sosial yang digunakan dalam penelitian ini bersumber dari Kementrian PDT.

\section{Teknik Analisis Data}

\section{Analisis Deskriptif - Kualitatif}

Analisis deskriptif didalam penelitian ini digunakan untuk mengkaji dinamika kemiskinan, perekonomian dan dana bantuan sosial di kabupaten tertinggal yang merujuk pada data tingkat kemiskinan, pertumbuhan ekonomi dan data bantuan sosial dari data BPS dan Kementerian PDT dari tahun 2009 sampai dengan 2013 pada daerah-daerah tertinggal yang berada di wilayah Barat (KBI) maupun Timur Indonesia (KTI).

\section{Analisis Kuantitatif - Regresi Data Panel}

Pada penelitian ini analisis regresi yang digunakan adalah analisis regresi data panel yaitu data time series selama 5 tahun bantuan sosial KPDT, serta data cross section dari masing-masing kabupaten tertinggal di Indonesia. Variabel-variabel lain yang mempengaruhi pertumbuhan ekonomi juga dimasukkan didalam model ini. Pemilihan faktor-faktor yang mempengaruhi pertumbuhan ekonomi, didasarkan oleh berbagai variabel yang digunakan dalam penelitian-penelitian terdahulu, dimana variabel-variabel tersebut berpengaruh signifikan terhadap pertumbuhan ekonomi:

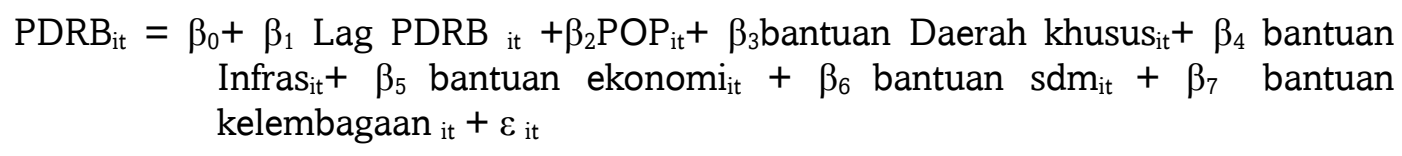

PDRB it

bantuan sdm it

bantuan Infras it

bantuan ekonomi it

Bantuan daerah khusus it

bantuan kelembagaan it

POP it

Lag PDRB it

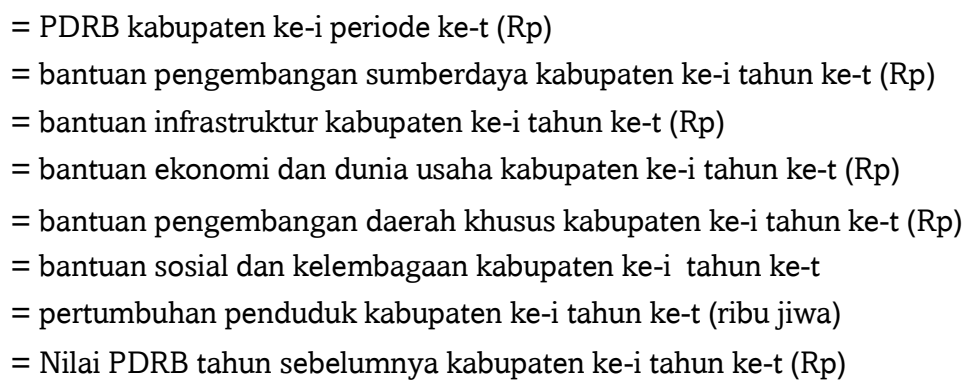

Sedangkan model data panel untuk kemiskinan dalam penelitian ini adalah sbb:

$(\mathrm{Y})_{\text {it }}=\beta_{0}+\beta_{1}$ PDRB $_{\text {it }}+\beta_{2}$ Pengangguran $_{\text {it }}+\beta_{3}$ IPM $_{\text {it }}+\beta_{4}$ share sector pertanian $_{\text {it }}+$ $\beta_{5}$ share sektor industri it $+\beta_{6}$ share sektor jasa it $+\varepsilon_{\text {it }}$

$\begin{array}{ll}\mathrm{Y}_{\text {it }} & =\text { Tingkat kemiskinan kabupaten ke-i periode ke-t }(\%) \\ \mathrm{PDRB}_{\text {it }} & =\text { PDRB Kabupaten ke-i periode ke-t (Rp) } \\ \text { Pengangguran it }_{\text {IPM }} & =\text { Tingkat pengangguran kabupaten ke-i periode ke-t }(\%) \\ \text { Agrishare }_{\text {it }} & =\text { Nilai IPM kabupaten ke-i periode ke-t (indeks) } \\ \text { Industri Share }_{\text {it }} & =\text { Share sektor pertanian dalam PDRB }(\%) \\ \text { Jasa Share }_{\text {it }} & =\text { Share sektor industri dalam PDRB }(\%) \\ & =\text { Share sektor jasa dalam PDRB }(\%)\end{array}$


Hasil Dan Pembahasan

Dinamika Kemiskinan, Pertumbuhan Ekonomi dan Bantuan Sosial di KBI dan KTI

\section{Dinamika Kemiskinan}

Rata-rata penurunan kemiskinan tertinggi di KBI adalah Provinsi Sumatera Barat sebesar 9 persen. Penurunan penduduk miskin diiringi dengan peningkatan perekonomian, dimana rata-rata pertumbuhan ekonomi tahun 2009-2013 sebesar 6,05 persen, lebih tinggi dari rata-rata pertumbuhan ekonomi daerah tertinggal di KBI 4,95 persen. Ketimpangan antar golongan masyarakat tidak terlalu besar, disebabkan mata pencaharian alternatif memberikan sumbangan cukup besar terhadap pendapatan rumah tangga, khususnya rumah tangga miskin yang menyebabkan tingkat ketimpangan di sumatera barat tidak terlalu besar (Amar, 2002).

Provinsi Sumatera Utara dan Kepulauan Riau mengalami peningkatan persentase jumlah penduduk miskin, dengan rata-rata peningkatan sebesar 14 persen dan 21 persen. Peningkatan kemiskinan diiringi dengan kecilnya pertumbuhan ekonomi di Kepulauan Riau yaitu 3,22 persen yang paling rendah dibandingkan dengan 10 provinsi lainnya yang berada di KBI. Pertumbuhan ekonomi yang kecil juga dialami Provinsi Sumatera Utara yaitu sebesar 4,04 persen. Artinya terdapat korelasi antara peningkatan persentase kemiskinan dengan pertumbuhan ekonomi di kedua provinsi tersebut. Rendahnya pertumbuhan ekonomi antara lain disebabkan kecilnya nilai tambah sektor unggulan daerah, kecilnya peningkatan pengeluaran pemerintah, dan tingginya tingkat pengangguran ( Simamora dan Sirojuzilam, 2008)

Provinsi Kalimatan Timur mengalami penurunan persentase penduduk miskin paling tinggi di KTI yaitu 11 persen. Penurunan kemiskinan diiringi dengan peningkatan pertumbuhan ekonomi sebesar 6,25 persen. Penerapan Kebijakan progrowth, pro-poor dan pro-human development mampu meningkatkan kesejahteraan masyarakat, ditandai dengan peningkatan pertumbuhan PDRB perkapita secara signifikan, peningkatan indeks IPM serta menurunnya persentase penduduk miskin di hampir seluruh kabupaten di Kalimantan timur (Amarullah, 2012).

\section{Dinamika Pertumbuhan Ekonomi}

Rata-rata pertumbuhan ekonomi kabupaten tertinggal di Kawasan Barat Indonesia adalah 4,95 persen selama periode 2009-2013. Rata-rata tertinggi dicapai oleh Provinsi Jawa Timur, dengan nilai pertumbuhan 6,12 persen. Sektor yang memicu perkembangan perekonomian di jawa Timur adalah jasa pengangkutan dan sektor bahan-bahan setengah jadi yang mampu menyumbang output 125 Trilyun bagi Jawa Timur (I dewa, 2013)

Rata-rata pertumbuhan ekonomi terendah adalah Kepulauan Riau dengan 3,22 persen. Kabupaten Natuna dan Kepulauan Anambas di kepualauan riau memiliki tingkat pertumbuhan yang selalu meningkat, hanya saja persentase pertumbuhannya tidak signifikan. Sektor yang berkembang adalah industri pengolahan, namun masih terdesentralisasi di Kota Batam, sehingga multiplier efek nya tidak berimbas pada kabupaten tertinggal. Berkembangnya sektor industri menyebabkan kontribusi sektor pertanian dalam perekonomian semakin kecil, sedangkan tenaga kerja masih dominan berada disektor pertanian, inilah yang menyebabkan mengapa pertumbuhan ekonomi menjadi lambat di Kepulauan Riau ( Maryanti, 2009). 


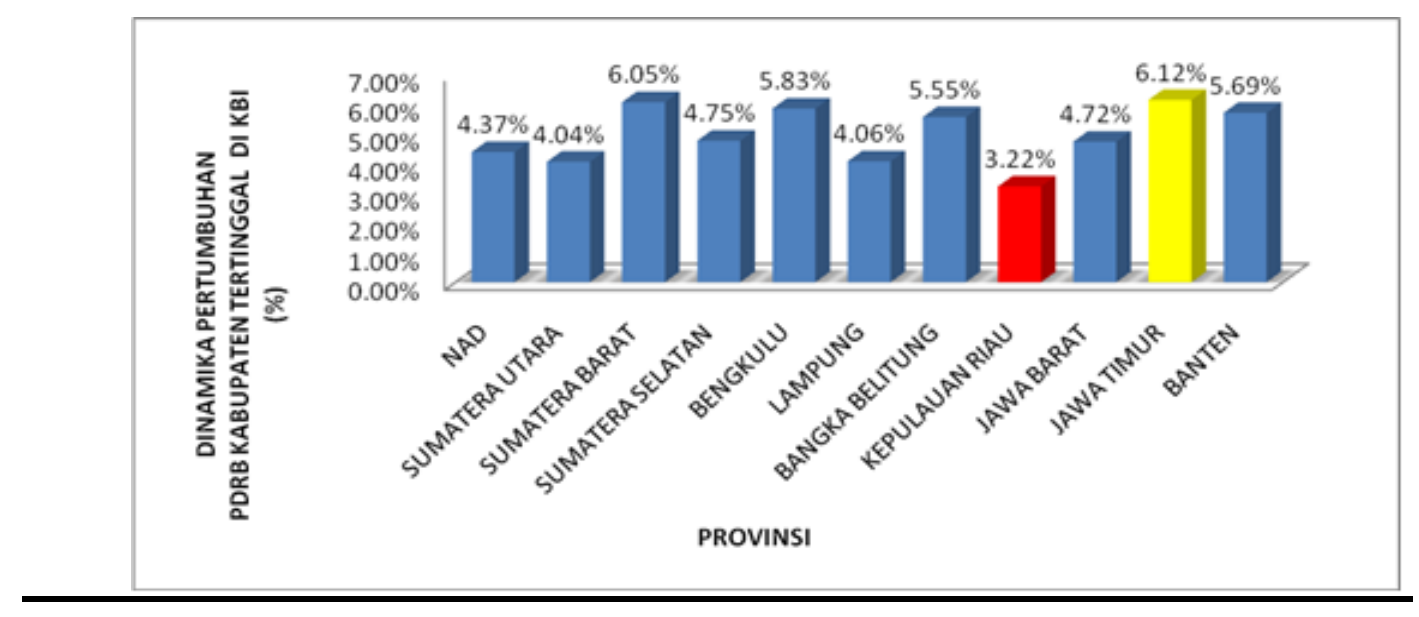

\section{Gambar 1 Rata-Rata Pertumbuhan Ekonomi Kabupaten Tertinggal Di Kawasan Barat Indonesia Tahun 2009-2013 (Persen)}

Persentase pertumbuhan ekonomi daerah tertinggal di KTI adalah 6,93 persen. Rata-rata Pertumbuhan ekonomi tertinggi adalah Papua Barat dengan 27,12 persen. Kondisi berbeda terjadi di Provinsi Papua yang mengalami penurunan pertumbuhan ekonomi sebesar 3,14 persen.

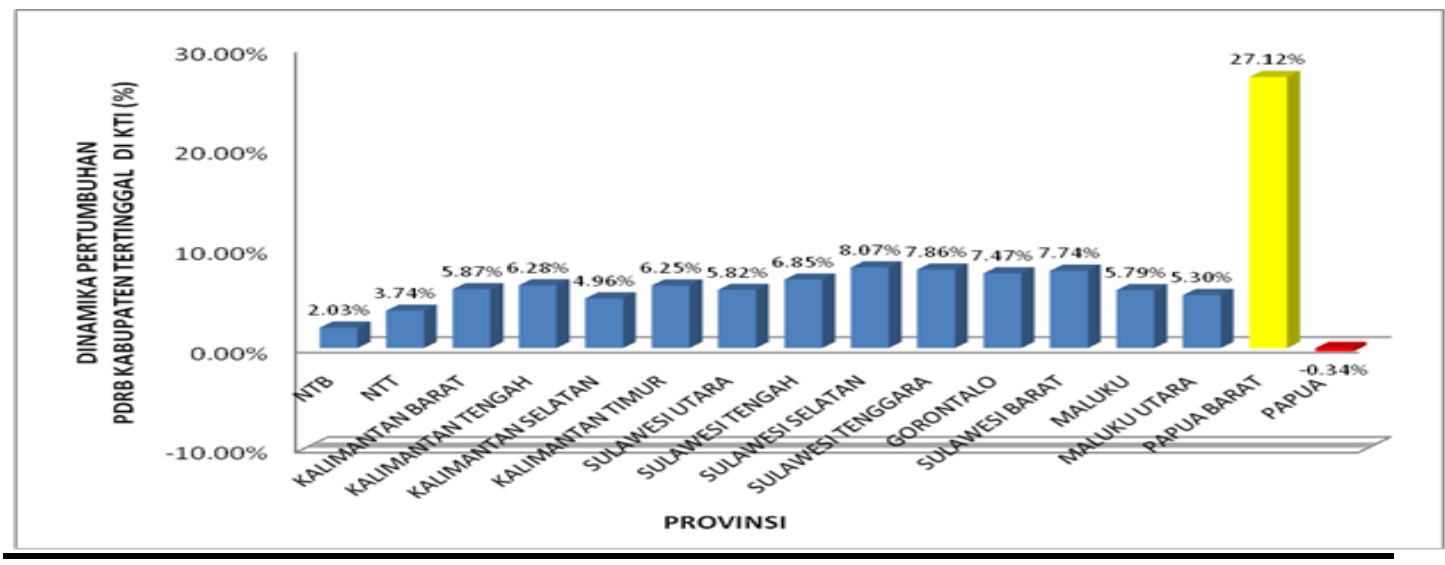

\section{Gambar 2 Rata-Rata Pertumbuhan Ekonomi Kabupaten Tertinggal Di Kawasan Timur Indonesia Tahun 2009-2013 (Persen)}

Kabupaten Mimika merupakan penyumbang terbesar PDRB Provinsi Papua namun tidak mampu keluar dari kondisi status tertinggal, walaupun potensi sumberdaya alam tambang emas yang dimilikinya sangatlah berpotensi untuk mensejahterakan masyarakatnya. Disisi lain kebijakan otonomi khusus yang diberikan untuk provinsi belum berhasil meningkatkan perekonomian dan kesejahteraan masyarakat. Kegagalan tersebut antara lain disebabkan : (1) adanya ketidaksamaan dalam pemahaman dan persepsi tentang otonomi khusus antara pemerintah daerah, pemerintah pusat, dan masyarakat, (2) terlambatnya penyusunan peraturan pelaksanaan baik dalam bentuk peraturan pemerintah (PP), Peraturan Daerah (Perda), (3) kebijakan otonomi khusus membuka peluang bagi beberapa pihak yang tidak bertanggung jawab untuk melakukan korupsi dan pemborosan dana otonomi khusus ( Wulandari dan Sulistio, 2013). 


\section{Dinamika Bantuan Sosial}

Sampai tahun 2013 telah diberikan bansos ke 183 daerah dengan persentase untuk pengembangan SDM sebanyak 5 persen, peningkatan infrastruktur 36 persen, pembinaan ekonomi dan dunia usaha 20 persen, pembinaan lembaga sosial dan budaya 4 persen dan pengembangan daerah khusus sebanyak 35 persen.

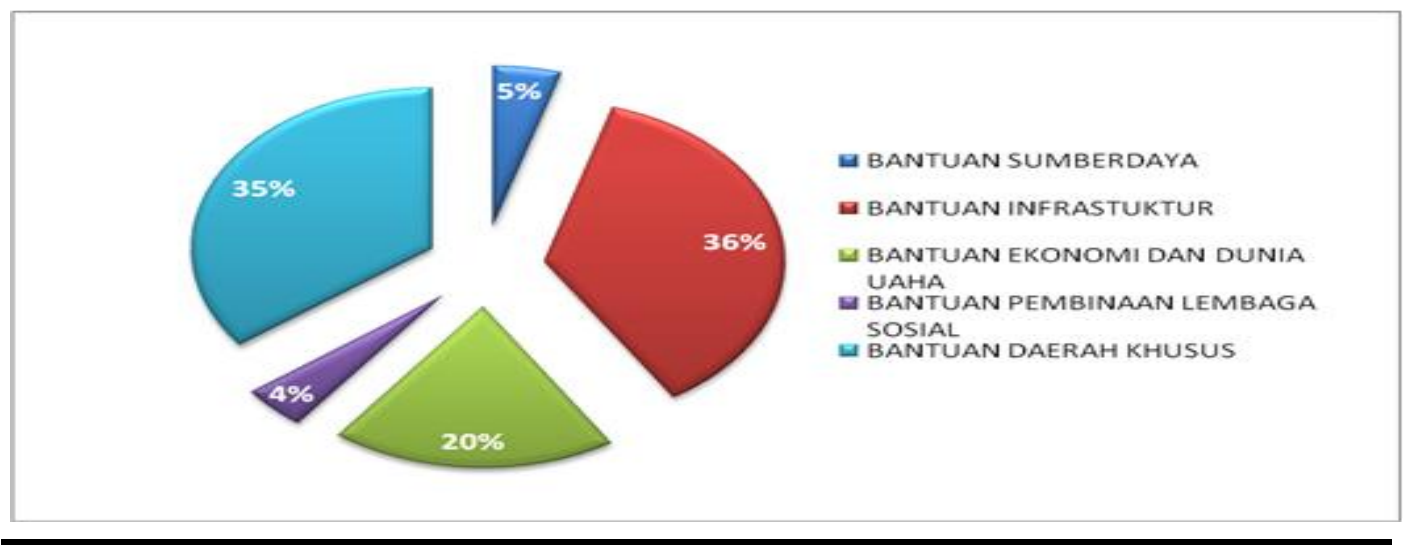

Gambar 3 Persentase Dari Masing-Masing Bantuan Sosial yang Disalurkan Kementerian PDT Tahun 2010-2013

Bantuan pembangunan infrastruktur merupakan bantuan yang paling besar diberikan untuk daerah tertinggal. Bantuan Pembangunan infrastruktur daerah tertinggal melalui penyediaan sarana dan prasarana transportasi, informasi dan telekomunikasi, sosial, ekonomi dan energi diharapkan menjadi stimulan kegiatan utama perekonomian. Percepatan pembangunan infrastruktur daerah tertinggal sangat diperlukan untuk mengurangi ketimpangan pembangunan dengan daerah non tertinggal. Bantuan infrastruktur ekonomi seperti pembangunan jaringan jalan, transportasi, listrik, berkontribusi terhadap output kedaerahan, pendapatan dan pertumbuhan lapangan kerja, serta meningkatkan kualitas hidup. Pengeluaran di bidang infrastruktur berpengaruh secara positif terhadap kinerja makro ekonomi karena kenaikan biaya pengeluaran di bidang infrastruktur mengurangi biaya produksi perusahaan, menstimulasi investasi, produktivitas dan pertumbuhan ekonomi. Dalam hal ini pemerintah tidak menciptakan lapangan kerja secara langsung namun membantu menciptakan suasana kondusif dalam investasi.

70 persen dari total bantuan infrastruktur diberikan untuk daerah tertinggal di KTI, dan 30 persen diberikan untuk daerah tertinggal di KBI. Bantuan infrastruktur paling besar diberikan untuk provinsi Nusa Tenggara Timur. Ketertinggalan pembangunan di provinsi NTT cukup tinggi, dimana semua kabupaten yang ada di Provinsi NTT masuk dalam status kabupaten tertinggal. Berbagai program dilakukan untuk meningkatkan pembangunan di NTT, namun terdapat berbagai keterbatasan untuk mengembangkan potensi daerah NTT ( Wehelmina et al, 2013), antara lain sarana transportasi dan pelabuhan laut yang mengakibatkan 5 (lima) pulau terdepan NTT tidak dapat dimanfaatkan potensinya secara baik. Sarana perhubungan antar pulau besar ke pulau kecil masih sangat terbatas dan tradisional.

Bantuan infrastruktur untuk provinsi NTT dilakukan untuk pembangunan perumahan dan pemukiman, pembangunan air minum, serta pembangunan sanitasi. Infrastruktur sosial secara mendetail dilakukan di Flores Timur dan Ende dengan 
pengembangan infrastruktur sarana dan prasarana air bersih. Pembangunan ekonomi produktif juga dilakukan, yaitu peruntukan kawasan pertanian yang terdiri atas kawasan tanaman pangan, hortikultura dan perkebunan seperti cengkeh, kelapa, kopi, jambu mete, vanili dan kemiri. Produk pertanian tanaman pangan adalah salah satu sektor utama bagi peningkatan ketahanan pangan dan kesejahteraan petani di NTT. Di beberapa Kabupaten seperti di kabupaten Ngada dikembangkan industri pembuat tepung pisang, yang diberikan di Kecamatan Golewa, Watuwawi Desa Were III dan Desa Sobo. Infrastruktur penunjang seperti pembangunan irigasi juga dibangun, antara lain di kabupaten Sumba Timuruntuk rehabilitasi irigasi di Kambera Kelurahan Mauliru dan Kelurahan Lambanapu.

\section{Analisis Pengaruh Bantuan Sosial Terhadap Perekonomian Kabupaten Tertinggal}

Hasil Estimasi menunjukkan bahwa bantuan infrastruktur, bantuan ekonomi dan dunia usaha, dan bantuan kelembagaan sosial pada taraf nyata 5 persen mempengaruhi tingkat pertumbuhan ekonomi di kabupaten tertinggal. Sedangkan bantuan sumberdaya manusia dan bantuan daerah khusus tidak signifikan mempengaruhi pertumbuhan ekonomi.

Tabel 1 Hasil Estimasi Pengaruh Bantuan Sosial Terhadap Pertumbuhan Ekonomi

\begin{tabular}{lccc}
\hline \multicolumn{1}{c}{ Variabel } & Koefisien & t-Stat & Prob \\
\hline Intercept & $-1395,689$ & $-38,26774$ & 0,0000 \\
Jumlah Penduduk & 0,002015 & 24,36362 & 0,0000 \\
Bantuan Daerah Khusus & $2,38 \mathrm{E}-08$ & 0,636428 & 0,5423 \\
Bantuan Infrastruktur & 18,87898 & 2,348317 & 0,0468 \\
Bantuan Ekonomi & $1,03 \mathrm{E}-08$ & 3,465684 & 0,0085 \\
Bantuan SDM & $1,35 \mathrm{E}-07$ & 1,055130 & 0,3222 \\
Bantuan kelembagaan Sosial & $9,49 \mathrm{E}-06$ & 0,0000 \\
Lag Pdrb & 9,428536 & 9,182494 & 0,0000 \\
R2 & 0,995821 & 51,85352 & \\
Adjusted R2 & 0,992164 & & \\
F-Stat & 272,3222 & & \\
Prob(F-Stat) & 0,000000 & & \\
DW-Stat & 1,709869 & & \\
\hline
\end{tabular}

Koefisien regresi jumlah penduduk 0,002015, artinya setiap kenaikan seribu jumlah penduduk meningkatkan nilai pdrb sebesar 0,002015 miliar. Pertumbuhan ekonomi dipengaruhi oleh dua faktor, yaitu faktor ekonomi, dan faktor non ekonomi salah satunya adalah faktor kependudukan (Jhingan, 2000). Penduduk merupakan unsur penting dalam usaha untuk meningkatkan produksi dan mengembangkan kegiatan ekonomi (Sukirno,1985). Jumlah penduduk yang terus bertambah akan memperbesar jumlah tenaga kerja, dan pertumbuhan tersebut memungkinkan negara atau daerah untuk menambah produksi (Rosyetti, 2009). Hasil analisis ini didukung oleh hasil penelitian sebelumnya oleh Savas (2008) yang menyatakan bahwa terdapat hubungan yang kuat dan positif antara pertumbuhan penduduk dengan pertumbuhan ekonomi.

Koefisien regresi bantuan infrastruktur 18,87898. Artinya, setiap kenaikan 1 Miliar bantuan meningkatkan nilai PDRB 18,87898 miliar. Perpres No 90 Tahun 2006, menjadi dasar hukum pelaksanaan Percepatan Pembangunan Infrastruktur 
Pedesaan Daerah Tertinggal (P2IPDT), P2IPDT merupakan kegiatan pokok dari pemerintah kepada daerah tertinggal di bidang pembangunan infrastruktur melalui penyediaan sarana dan prasarana transportasi, informasi dan telekomunikasi, sosial, ekonomi dan energi. Canning dan Pedroni (1999) serta Seetanah, Ramessur dan Rojid (2009) menyatakan bahwa infrastruktur transportasi merupakan infrastruktur yang menyumbang kontribusi terbesar pada pertumbuhan. Efek pembangunan infrastruktur terhadap perekonomian akan dirasakan dalam jangka menengah dan jangka panjang (Sari, 2011).

Koefisien regresi bantuan kelembagaan dan sosial 9,49 E-06, artinya kenakan 1 miliar bantuan meningkatkan nilai PDRB sebesar 9,49 miliar. Muhammad dan Sufri (2013) menyatakan bahwa dalam rangka menunjang kelembagaan masyarakat desa, dilakukan kegiatan : (1) pelatihan partisipatif kelompok, dan (2) sosialisasi serta pendampingan. Penguatan kelembagaan melalui kegiatan pendampingan dibutuhkan untuk penguatan kelembagaan masyarakat desa dan kegiatan pemberdayaan. Kegagalan suatu program bisa terjadi karena tidak adanya pendampingan ataupun karena pendampingan tersebut dilakukan oleh orang yang kapasitasnya terbatas. Program dan kegiatan diarahkan untuk meningkatkan kapasitas kelembagaan masyarakat desa melalui pengembangan kualitas SDM dan penguatan organisasi masyarakat desa, dilakukan dengan pemberiaan pembinaan, pengendalian, evaluasi dan penyusunan laporan kegiatan lembaga, dan dilaksanakan dengan kerjasama antara kementerian PDT, pendamping manajemen nasional (PMN), tenaga pendamping provinsi (TPP), tenaga pendamping kabupaten (TPK), tenaga fasilitator desa (TFD), serta instansi terkait lainnya (Kementerian PDT, 2013).

Koefisien regresi bantuan ekonomi dan dunia usaha 1,03E-08, artinya adalah kenaikan bantuan 1 miliar akan meningkatkan nilai PDRB sebesar 1,03 miliar. Kegiatan terkait bantuan ini adalah pengembangan produk atau komoditas unggulan daerah, pemberian bantuan kredit dengan syarat yang tidak memberatkan, , bantuan keahlian, penyuluhan, dan melalui usaha-usaha pengembangan kewirausahaan. Pengembangan komoditas unggulan memberikan nilai tambah yang tinggi sehingga meningkatkan perekonomian masyarakat (Azwartika dan Sardjito. 2013), ditambah dengan kemudahan akses untuk mendapatkan kredit usaha tani menyebabkan meningkatnya produktifitas kegiatan usaha tani masyarakat (Sisilia , Aritonang, Kurniati, 2012). Pengembangan produk atau komoditas unggulan daerah menjadi program utama bantuan ekonomi dan dunia usaha, seperti yang dilakukan di Nusa Tenggara Timur dan Sumatera Selatan, dimana dikembangkan perkebunan kakao, karet, jagung dan penangkapan ikan untuk membantu perekonomian masyarakatnya.

\section{Analisis Pengaruh Pertumbuhan Ekonomi Terhadap Penurunan Kemiskinan Di Kabupaten Tertinggal Di Indonesia}

Hasil estimasi menunjukkan bahwa variabel PDRB tidak signifikan mempengaruhi tingkat kemiskinan di daerah tertinggal. Variabel yang signifikan mempengaruhi tingkat kemiskinan di daerah tertinggal adalah tingkat pengangguran, ipm, dan share sektor jasa

Variabel tingkat pengangguran berkorelasi positif terhadap jumlah penduduk miskin di kabupaten tertinggal di Indonesia. Nilai koefisien regresi pengangguran sebesar 0,306213 yang berarti setiap kenaikan pengangguran sebesar 1 persen, akan meningkatkan jumlah penduduk miskin sebesar 0.306213 persen. Ditingkat regional sektor non riil tumbuh sangat cepat sedangkan sektor riil yang mampu menyerap tenaga kerja malah tumbuh lambat (BPS, 2014). Dengan lambatnya pertumbuhan sektor riil daya serap tenaga kerja menjadi sangat rendah, ditambah dengan kenaikan 
harga BBM semakin menurunkan daya saing sektor riil dan semakin menurunkan kemampuan daya beli masyarakat. Rendahnya daya serap perekonomian terhadap tenaga kerja berakibat semakin meningkatnya tingkat pengangguran, yang diiringi dengan peningkatan tingkat kemiskinan. Untuk mengurangi tingkat pengangguran akibat rendahnya pertumbuhan sektor riil maka pemerintah harus menciptakan pertumbuhan ekonomi tinggi dan berkualitas untuk menyerap tenaga kerja. Kualitas SDM didaerah tertinggal menunjukkan peningkatan yang dapat dilihat dari peningkatan kualitas hidup dan mutu pendidikan, meskipun masih belum merata dibeberapa wilayah tertentu (Mangedaby dan Sugiri, 2014). Beberapa hal yang menyebabkan kondisi ini antara lain belum tersedianya pendidikan dasar secara merata di daerah tertinggal. kondisi ini menyebabkan banyaknya tenaga kerja yang tidak berkualitas dan munculnya kelompok pengangguran yang permanen (Lukman, 2009).

Nilai koefisien regresi IPM sebesar -1.477 yang berarti setiap kenaikan 1 indeks IPM akan menurunkan jumlah penduduk miskin sebesar 1, 477 persen. Hasil evaluasi RPJMN 2010-2014 oleh BAPPENAS, peningkatan kualitas SDM di daerah tertinggal ditunjukkan dengan peningkatan rata-rata indeks pembangunan manusia menjadi 67,48 (Bappenas 2014). Program peningkatan kualitas SDM berada di bawah Deputi 1 Kementerian PDT, kegiatan yang dilakukan adalah pemberdayaan dan pelatihan untuk meningkatkan keterampilan masyarakat. Hasil studi oleh Eleonora, Muhammad, Arip (2014) dengan judul human development and poverty in Papua province, juga menyatakan bahwa pemberian bantuan untuk peningkatan pendidikan dan kualitas kesehatan dapat meningkatkan kualitas sumberdaya manusia dan dapat menurunkan kemiskinan.

Tabel 2 Hasil Estimasi Model Kemiskinan

\begin{tabular}{lccc}
\hline \multicolumn{1}{c}{ Variabel } & Koefisien & t-Stat & Prob \\
\hline Intercept & 150,3139 & 6,681331 & 0,0000 \\
PDRB & $-1,51 \mathrm{E}-06$ & $-0,066362$ & 0,9471 \\
Pengangguran & 0,306213 & 1,779405 & 0,0758 \\
IPM & $-1,477162$ & $-4,384534$ & 0,0000 \\
Jasa & $-0,035118$ & $-2,659057$ & 0,0000 \\
Industri & $-0,001950$ & $-0,559357$ & 0,5762 \\
Agrishare & $-0,001569$ & $-0,258120$ & 0,7964 \\
R & 0,993351 & & \\
Adjusted R & 0,990809 & & \\
F-Stat & 390.8981 & & \\
Prob(F-Stat) & 0,000000 & & \\
DW-Stat & 1,895216 & & \\
\hline
\end{tabular}

Koefisien regresi sektor jasa $-0,035118$, artinya 1 persen kenaikan nilai sektor jasa dalam pdrb akan menurunkan tingkat kemiskinan dikabupaten tertinggal 0,035118 persen. Struktur pertumbuhan ekonomi Indonesia pada umumnya lebih banyak dihela oleh pertumbuhan di sektor nontradble (jasa) dan konsumsi. Pada saat terjadi krisis 1997-1998, sektor jasa merupakan salah satu sektor yang mampu bertahan dan dapat menyerap tenaga kerja, khususnya tenaga kerja yang pindah dari sektor formal ke sektor informal (Suradi, 2011). Sektor informal dalam sektor jasa memiliki keunggulan, yaitu merupakan sektor yang dinilai tahan terhadap resesi dan dapat menjadi kekuatan ekonomi nasional (Kasali, 2010). Di Negara berkembang 
seperti indonesia sektor informal memang lebih banyak menyerap tenaga kerja dibandingkan dengan sektor formal ( Suradi, 2011). Pada tahun 2010 sekitar 90,8 juta penduduk Indonesia bekerja di sektor informal, jumlah tersebut sekitar 50,7 juta merupakan jenis usaha informal (Kasali, 2010).

\section{Kesimpulan Dan Saran}

\section{Kesimpulan}

1. Dinamika penduduk miskin dan pertumbuhan ekonomi antara KBI dan KTI berfluktuasi selama tahun 2010-2013. Dinamika bantuan sosial , jika dilihat dari share bansos selama tahun 2010-2013, bantuan infrastruktur menjadi bantuan yang mempunyai porsi paling besar dalam pembagian bansos.

2. Bantuan sosial yang signifikan mempengaruhi pertumbuhan ekonomi daerah tertinggal adalah bantuan ekonomi dan dunia usaha, bantuan kelembagaan sosial budaya, dan bantuan infrastruktur.

3. PDRB daerah tertinggal tidak signikan mempengaruhi tingkat kemiskinan di daerah tertinggal. Variabel yang signifikan mempengaruhi Tingkat kemiskinan didaerah tertinggal adalah tingkat pengangguran, IPM, dan share sektor jasa

\section{Saran}

1. Untuk meningkatkan PDRB dan mempercepat penurunan kemiskinan di daerah tertinggal, pemerintah melalui kementerian PDT dapat meningkatkan pemberian bantuan sosial kepada daerah tertinggal khususnya bantuan yang dalam penelitian ini signifikan mempengaruhi tingkat pertumbuhan ekonom, yaitu bantuan infrastruktur, bantuan ekonomi dan dunia usaha, serta bantuan kelembagaan sosial dan budaya.

2. Untuk mempercepat penurunan tingkat kemiskinan, perlu peningkatan kualitas SDM di daerah tertinggal melalui bidang pendidikan. Hal ini sesuai dengan hasil dari penelitian ini dimana IPM berpengaruh signifikan terhadap penurunan tingkat kemiskinan.

\section{Daftar Pustaka}

Aziz IJ. 1994.Ilmu Ekonomi Regional dan Beberapa Aplikasinya di Indonesia. Jakarta: Lembaga Penerbit FEUI. (Maelissa 2010,Mulyana 2009, ).

[BPS] Badan Pusat Statistik. 2013. Distribusi Nilai PDRB Menurut Pulau Tahun 2008-2012. Jakarta: BPS

[BPS] Badan Pusat Statistik. 2014. Profil Kemiskinan di Indonesia Maret 2014. Jakarta: BPS

David, Canning. And Peter, Pedroni. 1999.Infrastructure and Long Run Economic Growth. World Bank and USAID CAER II Working Paper.

Eleonora, Muhammad, Arip Syaman Sholeh. Human Development and Poverty In Papua Provinces. OIDA International Journal Of Sustainable Development. Vol (06) Page 5162.2013

Eva Artmey, Mangedaby. dan Agung, Sugiri. Kajian Pembangunan Kawasan Tertinggal Di Kabupaten Grobogan.Jurnal Teknik PWK. Vol 3. No 2. 2014.

Hasan, M. dan Syufri. Persiapan Sosial dan Penguatan Kelembagaan Bagi Penerima Manfaat Dalam Menunjang Program REDD. Jurnal Academica Fisip Unpad.2013.

Jhingan, ML. 2000. Ekonomi Pembangunan dan Perencanaan.PT Raja Grafindo Persada.Jakarta

Rhenald, Kasali. 2010. Sektor Informal Jadi Kekuatan Ekonomi.Jakarta:http:/yea-indonesia.com 
Kementrian Pembangunan Daerah Tertinggal (PDT). 2013. Bantuan Sosial/Stimulan Kabupaten Tertinggal, Kementrian Negara Pembangunan Daerah Tertinggal. Jakarta: Kementrian PDT.

Kementerian Perencanaan Pembangunan Nasional 2014. Evaluasi Paruh Waktu RPJMN 2010-2014. Jakarta.Bappenas

Lukman, Edy. Pencapaian Pembangunan Daerah Tertinggal Lima Tahun Terakhir.Jurnal Sekretariat Negara.No 13. 2009.

Marganda, Simamora. dan Sirojozilam. 2008. Determinan Pertumbuhan Ekonomi Regional Sumatera Utara.Jurnal Perencanaan dan Pengembangan Wilayah.Vol 4. No 2.

Ratiza, Azwartika. dan Sardjito. 2013. Pengembangan Komoditas Unggulan Pertanian Dengan Konsep Agribisnis Di Kabupaten Pamekasan. Jurnal Teknik Pomits. Vol2.No2

Rosyetti. 2009. Studi Keterkaitan Pertumbuhan Penduduk Dengan Pembangunan Ekonomi Di Kabupaten Kuantan Singingi. Jurnal Ekonomi. Vol 17. No 2.

Rustan, Amarullah. 2012. Evaluasi Kinerja Kebijakan Pro Growth, Pro Poor, Pro-Human Development Di Provinsi Kalimantan Timur. Jurnal Borneo Administrator.Vol 8. No 1.

Perwitas, Sari. 2011. Analisis Pengaruh Program Pembangunan Infrastruktur Terhadap Kemiskinan di Kabupaten Tertinggal.[Tesis] Bogor: Institut Pertanian Bogor

Bilal, Savas. 2008. The Relationship Between Population And Economic Growth:Empirical Evidence From The Central Asian Economies. OAKA International Journal. Vol(3) Page 161-183.

Sadono, Sukirno.1985. Pengantar Teori Mikroekonomi. Jakarta . Lembaga Penerbit FEUI.

Syamsul, Amar. Kajian Ekonomi Tentang Kemiskinan di Perdesaan Propinsi Sumatera Barat.Jurnal Ekonomi Pembangunan.Vol 7 No 2. 2002

Setiawan, I Dewa. 2007. Peranan Sektor Unggulan Terhadap Pertumbuhan Ekonomi Daerah. Jurnal Socio-Economic Of Agriculture and Agribussines.Vol 7. No2.

Seetanah. Ramessur. Rojid. 2009. Does Infrastructure Alleviates Poverty In Developing Countries. International Journal of Applied Econometrics and Quantitative Study.

Sinta, Wulandari. dan Ekobudi, Sulistio. 2013..Otonomi Khusus Dan Dinamika Perekonomian Di Papua. Jurnal Ilmiah Administrasi Publlik dan Pembangunan.Vol. 4 No 1.

Sri, Maryanti. 2009. Analisa Pertumbuhan Ekonomi dan Tingkat Kemiskinan Di Provinsi Riau.Pekbis Jurnal. Vol 1. No (3).

Sisilia. Marisa, Aritonang. Dewi, Kurniati. 2012. Analisis Komparatif Pendapatan Petani Padi Penerima PUAP Dan Petani Non Penerima PUAP Di Desa Ngarak Kecamatan Mandor Kabupaten Landak. Jurnal Social Economic of Agriculture.Vol 1. No 3.

Suradi. 2011. Peranan Sektor Informal Dalam Penanggulangan Kemiskinan.Jurnal Informasi.Vol 16. No 3.

Wehelmina et al. 2013.Kajian Status Provinsi Nusa Tenggara Timur Sebagai Provinsi Kepulauan Di Tinjau Dari Perspektif Hukum. Jurnal Borneo Administrator.Vol 9. No 2. 